\title{
Hanna-Riikka Roine
}

\section{Mahdollistavat maailmat. Näkökulmia China Miévillen Embassytown-romaanin outouteen}

Miten fiktiivisiä maailmoja tehdään? Ja miksi niitä tehdään? Pyrin vastaamaan näihin kysymyksiin artikkelissani tarkastelemalla spekulatiivisen fiktion maailmojen rakentumista kahdesta lähtökohdasta. Yhtäl̈lä ihmisen ympäröivän todellisuuden ymmärtämisen prosessit voidaan nähdä maailmojen, eräänlaisten mentaalisten mallien, rakentamisena. Tämä tarkoittaa asioiden (kuten entiteettien, sijaintien ja tapahtumien) välisten suhteiden rakentamista ja niiden sitomista yhteen ymmärrettäväksi kokonaisuudeksi. Toisaalta kaunokirjallisten maailmojen luomisessa ei ole kyse pelkästään "inhimillisestä halusta luoda merkityksiä" (vrt. Fludernik 1993, 457) vaan myös hypystä kohti jotakin uutta, jota ei vielä ole olemassa. Fiktiivisten maailmojen luonne on siis perustavanlaatuisella tavalla kahtalainen: ne ovat sekä merkitysten ja yhteyksien luomisen että kuvittelun välikappaleita. Intuitiivinen käsitys etenkin fantastisista maailmoista korostaa niitä jälkimmäisessä merkityksessä, mielikuvituksellisina ympäristöinä, joissa fiktiiviset henkilöt toimivat ajaen päämääriään ja joissa monenlaiset tapahtumat ja pyrkimykset kehkeytyvät. Tällaiset ympäristöt voivat vaihdella kokonaisista yksityiskohtaisesti luoduista maailmankaikkeuksista omine kielineen ja kansoineen aina yksilöimättömään ja ilmeettömään tilaan asti.

Fiktiivisten maailmojen asema sekä merkitysten luomisen että kuvittelun välikappaleina tuottaa myös niiden kahtalaisen luonteen mahdottomina ja mahdollisina. Mahdottomuus on tietynlaista saavuttamattomuutta, jolla tarkoitan paitsi sitä, että kirjalliset maailmat ovat riippuvaisia ne luovasta tekstistä, myös sitä, että ne voivat lukijan näkökulmasta olla hyvin kaukaisia ja outoja. Näin on laita myös analyysiesimerkissäni, tämän hetken kiinnostavimpiin spekulatiivisen fiktion kirjoittajiin lukeutuvan China Miévillen tuoreessa romaanissa Embassytown (2011). Sen tapahtumat sijoittuvat meille tuntemattomalle Arieka-planeetalle, jolla ihmiset ja planeetan erikoislaatuinen alkuperäisrotu Ariekei (tai Isännät, Hosts) ovat viettäneet rauhanomaista yhteiseloa jo vuosikymmenien ajan. Tässä artikkelissa keskitytään siihen, kuinka fiktiiviset maailmat voivat tarjota keinon mahdottoman tavoittamiseen niin kaunokirjallisuuden luomisen kuin lukemisenkin kannalta. Teen mahdollisten maailmojen poetiikan ja narratologian keinoin avauksia sen tarkasteluun, kuinka Ariekasta voidaan oman maailmamme keinoin kertoa ja kuinka lukijoiden tekemä mielikuvituksellinen hyppy sinne oikein tapahtuu. 
Filosofisen logiikan puolella kehitetyt mahdolliset maailmat ovat abstrakteja konstruktioita, joiden tarkoituksena on havainnollistaa esimerkiksi lauseiden totuusarvoihin ja kontrafaktuaaleihin ${ }^{1}$ liittyviä teoreettisia pulmia. Logiikan käsitteet ja tavoitteet eivät olekaan sellaisinaan sovellettavissa kirjallisuuden tutkimukseen, sillä toisin kuin logiikan mahdolliset maailmat kirjallisuuden maailmat ovat konkreettisia taiteellisia ilmiöitä (vrt. Koskimaa 1999, 124). Mahdollisten maailmojen poetiikka voi silti tarjota kiinnostavan pohjan niin tällaisten taiteellisten ilmiöiden kuin niiden lukijoissaan synnyttämien mielikuvitusmaailmojen tarkasteluun. Tätä varten mahdollisista maailmoista on tehtävä kirjallisia ja luotava kurinalainen sanasto, jolla maailmoista ja niiden välisistä suhteista voidaan puhua (ks. Hägg 2005, 52). Kirjallisuustieteellisiä pyrkimyksiä tällaisen sanaston luomiseksi on jo tehty, ja keskeisimmät käsitteellistykset löytyvät narratogisen keskustelun piirissä. Thomas Pavel (1986), Lubomír Doležel (esim. 1998) ja Marie-Laure Ryan (esim. 1991 ja 2001) ovat kaikki liittäneet mahdollisten maailmojen käsitteistön nimenomaan kertomusteoreettisiin kysymyksiin.

Mahdollisten maailmojen poetiikan ${ }^{2}$ voi yksinkertaisimmillaan nähdä jäljittävän kerronnasta eräänlaista ohjeiden ja sääntöjen järjestelmää, jonka mukaan siinä kuvattu maailma rakentuu ja toimii. Ryan $(1992,554)$ on tiivistänyt sen tavoitteet toteamalla, että tarkoituksena ei ole tarjota tutkimuksellista ideologiaa vaan kokoelma analyyttisia työkaluja. Samuli Hägg $(2008,9)$ kuitenkin huomioi, että Ryanin väitteestä huolimatta mahdollisten maailmojen poetiikka tarjoaa oman ideologiansa esimerkiksi Pavelin ja Doleželin vaikutusvaltaisissa teorioissa: se korostaa yhtäältä kirjallisuuden maailmoja luovia ominaisuuksia ja toisaalta maailmojen merkitysten tekstuaalisia perusteita. Tämä nostaa esiin yhden mahdollisten maailmojen poetiikkaan nojaavan kirjallisuudentutkimuksen olennaisimmista haasteista: selvittää, mitä erityistä on kirjallisuuden, vieläpä tiettyjen teosten, tavassa synnyttää mahdollisia maailmoja tai niitä muistuttavia rakenteita (Hägg mt., 6). Tässä artikkelissa tartutaan juuri Häggin esittämään haasteeseen ja tarkastellaan, millaista käyttöä mahdollisille maailmoille voitaisiin kirjallisuustieteellisessä analyysissa keksiä silloin, kun tarkastellaan spekulatiivisen fiktion maailmoja. Samalla pohditaan sitä, kuinka maailmat puolestaan voivat hioa teoriaa.

\section{Outo Embassytown: Maailma jota ei vielä ole}

Tunnettu fantasia- ja tieteiskirjailija Ursula K. Le Guin toteaa arvostelussaan Miévillen romaanista, että onnistunut kaunokirjallisuus kuten Embassytown "ei ole laiskoja mieliä varten" (Le Guin 2011). Romaanin haasteellisuus perustuu osaltaan sen maailman kaukaisuuteen. Teoksen keskiössä on sen minäkertojana toimivan Avice Benner Chon tarina. Hän on immerseri: hänen työnään on matkustaa immerissä, joka on "jokapäiväisen tilan" alapuolella vellova aika-avaruuden meri. Avice palaa vastavihityn miehensä kanssa lapsuutensa kotiplaneetta Ariekalle, jossa ainoa linkki ihmisten ja Ariekein 
yhteisöjen välillä ovat geneettisesti tehtäväänsä suunnitellut lingvistit, Lähettilää, jotka kykenevät puhumaan Ariekein Kieltä. Ariekan rauhallinen elämä päättyy yllättäen, kun uusi, geneettisesti muuntelematon Lähettiläs EzRa saapuu ja aiheuttaa vaarallisen kriisin ihmisten ja Ariekein suhteissa. Avice pyrkii ratkaisemaan tilanteen ennen kuin se koituu kummankin rodun tuhoksi, mutta onnistuakseen siinä hänen olisi puhuttava suoraan Ariekeille. Valitettavasti tämä on mahdotonta, sillä Kielen sanat on puhuttava yhtäaikaisesti kahdella äänellä, joita yhdistää jaettu tietoisuus, ja mihinkään sellaiseen, jota ei aktuaalisesti ole olemassa, ei voida viitata: ${ }^{3}$

For Hosts, speech was thought. It was as nonsensical to them that a speaker could say, could claim, something it knew to be untrue as, to me, that I could believe something I knew to be untrue. Without Language for things that didn't exist, they could hardly think them; they were vaguer by far than dreams. What imaginaries any of them could conjure at all must be misty and trapped in their heads. (Embassytown, 96.)

Näinkin lyhyt tiivistelmä romaanista riittänee nostamaan esiin sen keskeiset kysymykset, jotka kietoutuvat kielen kahtalaiseen luonteeseen paitsi kommunikaation myös luomisen välineenä. Kuinka meidän on mahdollista kommunikoida jonkun sellaisen kanssa, joka on kovin erilainen kuin me itse? Entä kuinka voimme kuvitella asioita, joita ei vielä ole? Välittömämpi haaste Embassytownin lukijalle on kertomuksen sisällön ymmärtäminen, kun taas ilmaisun taso eli kerronta ei ole samalla tavalla outoa kuin vaikkapa kokeellisemmissa fiktion muodoissa. Teoksen fiktiivistä maailmaa voikin hyvällä syyllä kutsua kummalliseksi. ${ }^{4}$ Se on meille täysin mahdoton - monille meistä jopa etukäteen kuviteltavaksi. Lukijoina hämmennyksemme on ehkä luonteeltaan samankaltaista kuin niillä ihmisillä, joiden reaktioita ensivierailulla Ariekalle Avice kuvaa seuraavasti: "The theory is that we're hardwired with Terre biome, that every glimpse of anything not descended from that original backwater home, our bodies know we should not ever see." (Embassytown, 74.) Alkuhämmennyksestä huolimatta ihmiskieli, toisin kuin Ariekein Kieli, voi toimia mielikuvituksen välikappaleena. Sen avulla voimme kuvitella tapahtumia, olentoja ja kokonaisia maailmoja, jotka eivät mitenkään voi olla mahdollisia omassa arkitodellisuudessamme. Tässä ei ole mitään outoa. Missä Embassytownin kummallisuus siis piilee - sen fantastisuudessako?

Mahdollisten maailmojen välineistöllä fantastisuutta ${ }^{5}$ on pohdittu jonkin verran: Nancy H. Traill (1996, 11-20) esimerkiksi on laatinut typologian fantasiakerronnan maailmojen kuvaamista varten. Mahdollisten maailmojen kehyksen ulkopuolella etenkin "sekundaaristen maailmojen fiktion"6 teoksia, jollaiseksi Embassytown voidaan lukea, on pitkään tarkasteltu erillisinä kokonaisuuksinaan. Tällaisen fiktion luku- ja tulkintatavoille on tyypillistä nähdä siinä luodut maailmat itsenäisinä verrattuna todellisuuteen, ei sen osina. Mahdollisten maailmojen poetiikka liittoutuu niin fantasiafiktion tutkimuksen kuin sen luku- ja kirjoitustapojenkin kanssa, sillä se tarjoaa analyyttisiä välineitä 
fiktiivisten maailmojen tarkasteluun juuri kokonaisuuksina. Maailmojen merkityksestä fantasiafiktiossa kertoo myös Miévillen itsensä tapa nähdä maailmojen rakentaminen erän̈laisena painopisteen siirtymänä pois juonikeskeisestä kirjoittamisesta. Hän kuvaa sitä kirjailijan näkökulmasta seuraavasti: "Paradigman vaihdos [--] edustaa tavallisesta poikkeavaa inversiota, joka suo kertomukselle omat erityistyökalunsa ja -kykynsä. Järjestys on päinvastainen: maailma tulee ensin, ja sitten, vasta sitten, asiat tapahtuvat tarinat syntyvät - sen sisällä." (Miéville 2009.) 7 Tämä ”ensin tuleva maailma” on Miévillelle luovan kirjoittamisen keskeinen ainesosa, koko prosessin mahdollistava maailma.

Fantastisten maailmojen outouden yhteydessä on usein korostettu fysikaalisen mahdottomuuden merkitystä. Maria Ihonen $(2002,200)$ viittaa estetiikan perustaja Alexander Gottlieb Baumgartenin erotteluun kerrotuista maailmoista: todet kuvitelmat (figment avera) ovat aktuaalisessa maailmassa mahdollisten asioiden representaatioita, kun taas rajoittamattomat kuvitelmat (figmenta simpliciter) representoivat niitä asioita, jotka ovat aktuaalisuuden kannalta mahdottomia. Ihosen näkemyksen mukaan mahdollisten maailmojen pohjalta voisi ajatella, että Embassytownissa kuvattu maailma Arieka-planeettoineen on fantastinen, koska se on fysikaalisesti mahdoton maailma. Siinä rikotaan luonnonlakeja (esimerkiksi outojen olentojen kuten Ariekein kohdalla), eikä sinne voi päästä mitään "luonnollista" reittiä. Toisaalta kaunokirjalliset maailmat, olivat ne sitten fantastisia tai eivät, ovat riippuvaisia kerronnan tuottamista representaatioista. Käytännössä ne siis ovat aina mahdottomia lukijoilleen. Tästä syystä fantasiatutkija Christine Brooke-Rose (1986, 320) on kutsunut "koko mimesiksen ideaa" illuusioksi, sillä kerronta ei voi imitoida sitä kertomusta, jota se on kertomassa. Kirjallisten maailmojen illusorisuus liittyykin tapaan, jolla ne piilottavat keinotekoisuutensa. Tämä ajatus (johon palaan tarkemmin jäljempänä) heijastuu jo klassisessa ars est celare artem -lausahduksessa (vapaasti käännettynä: "taidetta on kätkeä taide").

Kenties etsimme outoutta väärästä paikasta, jos paikannamme sen tapoihin, joilla kuvitteelliset maailmat eroavat konsensustodellisuudesta - joka sekin voidaan nähdä illuusiona, johon liittyvillä oletuksillamme spekulatiivinen fiktio usein leikittelee. Kuten edellä totesin, kaikkia fiktion maailmoja yhdistää se, että ne ovat, toisin kuin todellinen maailma, riippuvaisia ne luovista keinoista. Tästä syystä eräänä lähtökohtana mahdollisten maailmojen poetiikassa on ollut fiktion näkeminen mahdollisena asioiden kulkuna tai tilana suhteessa todellisuuteen. Embassytownin esittämiä mahdollisuuksia, kuten kahdella suulla yhtä aikaa puhuvia Ariekei-olentoja, on kuitenkin vaikeaa verrata mihinkään. Ne eivät ole symboleita tai allegorioita vaan materiaalinen osa fiktiivistä maailmaa, olennaisia omana itsenään. Traill $(1996,9)$ on muotoillut tämän ongelman hieman pidemmälle mahdollisten maailmojen poetiikan kehyksessä: "[T]eos on fantastinen, jos fiktiivinen maailma koostuu kahdesta aleettisesti vastakkaisesta alueesta, luonnollisesta ja yliluonnollisesta.” Tässä mielessä fantastiset maailmat ovat hybridisiä: ne sisältävät alueen, joka on aktuaalisen maailman kaltainen vaikkapa luonnonlakien 
noudattamisen suhteen (painovoima vaikuttaa Ariekallakin), mutta myös alueen, joka ei seuraa aktuaalisen maailman lakeja (vrt. Ihonen 2002, 201). Hybridisyys on yksi keino tarkastella sitä, kuinka fantastiset maailmat voivat yhtä aikaa olla todellisesta maailmasta erillisiä, mutta silti samaan aikaan haastaa sen. Niiden on mahdollista tarjota uusi, etäännytetty näkökulma johonkin lukijaa liian lähellä olevaan kysymykseen. Yksi esimerkki tällaisesta on käsityksemme sukupuolesta, jonka Le Guin nostaa esiin tarkastellessaan Avicea henkilöhahmona: "Mikään hänen käytöksessään ei viittaa tavanomaisiin feminiinisyyden tai ei-feminiinisyyden tunnusmerkkeihin." (Le Guin 2011.) Etäännyttäminen on vapauttava tulokulma eskapismista syytettyyn fantasiafiktioon, sillä se osoittaa, ettei kaukaisten maailmojen rakentaminen välttämättä tarkoita uppoutumista aitojen epäkohtien välttelyyn.

Tässä artikkelissa otan maailmojen hybridisyyteen hieman edellä esitetystä poikkeavan näkökulman, joka keskittyy fiktion maailmojen kahtalaiseen luonteeseen taiteellisina ilmiöinä ja kuviteltuina maailmoina. Tätä kautta on mahdollista tarkastella sitä, kuinka aktuaalinen lukuprosessi liittyy erilaisiin maailmoja rakentaviin kertovan tekstin piirteisiin. Konkreettisena taiteellisena ilmiönä fiktiivinen maailma voidaan nähdä "ensin tulleena maailmana", jolle Embassytownissa on annettu kaunokirjallisen ilmaisun ja keinojen mahdollistama asu. Arkikielessä näkemys tällaisesta maailmasta heijastuu sellaisissa ilmauksissa kuin puhuttaessa vaikkapa "Miévillen maailmasta", jolla tarkoitetaan Miévillen kuvittelemaa ja rakentamaa, todellisuudestamme erilliseksi miellettävää kokonaisuutta. Muunlaisesta fiktiosta Embassytownin kaltaiset työt eroavat juuri siinä, että ne tekevät maailmoista, inhimillisistä ympäristön hahmottamisen keinoista, niin konkreettisia. Fantastiset maailmat sisältävät henkilöiden, tapahtumien ja tekojen ohella myös niitä ympäröivän kontekstin kiinnekohtineen sekä sosio-historiallisine ja kulttuurisine ympäristöineen.

Fiktiivisen maailman kuvitteellista puolta valottaa J. R. R. Tolkienin (2002, 55) klassinen teoria, jonka mukaan sekundaarinen, primäärisestä maailmastamme erillinen, maailma syntyy kirjailijan ja lukijan yhdessä olettamana, kuvittelun tuloksena. Lukijalla on oikeus sukeltaa siihen, kun taas kirjailijalla on velvollisuus ylläpitää sen koherenssia. Kiinnostavaa kyllä, Tolkienin ajatukset muistuttavat Ryanin mahdollisten maailmojen poetiikkaan pohjaavaa erittelyä lukijan uppoutumisesta kaunokirjalliseen teokseen. Ryan, joka on vienyt Häggin peräänkuuluttaman kurinalaisen sanaston luomisen kenties kaikkein pisimmälle, kuvailee Tolkienin pohtimaa ilmiötä lukijan sukeltamisesta fiktiiviseen todellisuuteen toisenlaisin käsittein, kuten fiktiivisen uudelleenkeskittämisen (fictional recentering) avulla. Se siirtää kerrotun universumin keskuksen "aktuaalisesta aktuaalisesta maailmasta" (eli paljon puhutusta "todellisesta" maailmasta) aktuaalisena maailmana tekstissä esitettyyn maailmaan. Tämän maailman Ryan nimeää tekstuaaliseksi aktuaaliseksi maailmaksi (TAM): 
Siksi aikaa kun lukija on uppoutunut kaunokirjalliseen teokseen, mahdollisuuksien piiri keskittyy uudelleen sen sfäärin ympärille, jonka kertoja esittää aktuaalisena maailmana. Tämä uudelleenkeskittäminen työntää lukijan uuteen aktuaalisuuden ja mahdollisuuden järjestelmään. Lukija, joka on matkailijana tässä systeemissä, ei ainoastaan löydä uutta aktuaalista maailmaa (TAM) vaan lukuisia aktuaalisia mahdollisia maailmoja, jotka sijoittuvat sen ympärille. (Ryan 1991, 22.)

Ryanin lähestymistavassa fiktiivisestä universumista muodostuu kokonainen modaalinen rakenne, jossa tekstuaalinen maailma koostuu kerronnan aktuaalisina esittämistä asioista ja tekstuaalisen maailman "ympärille" sijoittuvista maailmoista. Yksi tämänkaltaisen mahdollisten maailmojen poetiikan vahvuuksista piileekin siinä, että se korostaa aktuaalisen ja virtuaalisen vuorovaikutusta kaunokirjallisten tekstien tulkinnassa. Ryanin edellä mainitsemat lukuisat aktuaaliset mahdolliset maailmat ovat muun muassa henkilöhahmojen sisäkkäismaailmoja: ”Aivan kuten me käsittelemme mahdollisia maailmoja mentaalisten toimintojemme kautta, niin tekevät myös fiktiivisten universumien asukkaat: heidän aktuaalinen maailmansa heijastuu heidän tiedoissaan ja uskomuksissaan, korjautuu heidän toiveissaan ja korvautuu uudella heidän unelmissaan ja harhoissaan.” (Ryan 1991, 123.) Tätä kautta voidaan havainnollisella tavalla nostaa esiin virtuaalisten konstruktioiden - uskomusten, toiveiden, pelkojen ja suunnitelmien - verkosto, joka paitsi motivoi fiktiivisten henkilöhahmojen toimintaa myös valottaa sitä, kuinka lukija hahmottaa tietyn maailman todenkaltaisena.

Toisaalta ajatus tekstuaalisesta aktuaalisesta maailmasta, jonka lukija rekonstruoi eli rakentaa uudelleen, on pohjaoletukseltaan ongelmallinen. Tällä tarkoitan etenkin sitä, että lukijan Embassytownin lukemisen aikana rakentama maailma ei edellä kerrontaa vaan on sen ymmärtämisen ja tulkinnan synnyttämä konstruktio. Se ei myöskään ole sama kuin edellä mainittu "Miévillen maailma”. Tekstin ja lukijan välisen vuorovaikutuksen kannalta onkin tärkeää tarkastella erilaisia keinoja tai elementtejä, jotka saavat lukijan kuvittelemaan maailmoja. Kognitiotieteistä ammentavassa kirjallisuudentutkimuksessa tämä on liitetty erityisesti tulkinnan kohteeksi ajateltuun kertomukseen. David Herman (2002, 13-14) esimerkiksi esittää, että pyrkiessään ymmärtämään kertomusta lukijat eivät rekonstruoi ainoastaan sitä, mitä tapahtui - kuka teki, missä teki, kenen kanssa, kuinka kauan, kuinka usein ja missä järjestyksessä - vaan myös tapahtumia ympäröivän maailman. Siihen on upotettu olemassa olevat asiat ominaisuuksineen sekä teot ja tapahtumat, joihin ne enemmän tai vähemmän osallistuvat. Hermanin ehdottama tarinamaailman (storyworld) käsite tavoittaakin onnistuneesti sen, että vaikka kaunokirjallinen teos on luonteeltaan ja ilmiasultaan peräkkäisyyteen pohjaava kielellinen esitys, lukuprosessin aikana syntyvä mentaalinen konstruktio ei ole lineaarinen linja. Hermanista poiketen pidän tarinamaailmaa aina keskeneräisenä työnä, jota jälkikäteen voi olla vaikeaa tavoittaa. Tällä perusteella se myös eroaa tarinasta (story), vaikka sekin nähdäkseni on tulkinnan tulos eikä sen enempää edusta jonkin- 
laista kausaalista logiikkaa, johon kertomus muotona pohjaisi. Tarina on kuitenkin enemmän selittävä lopputulos kuin tarinamaailman kaltainen välivaihe, jossa mitkä tahansa tekstin avaamat mahdollisuudet ovat vielä aktualisoitavissa toisin. Tulkintaprosessin jälkeen voi nimittäin olla mahdotonta hahmottaa niitä tulkintoja, jotka eivät jääneetkään voimaan. Lukijan voi olla jälkikäteen hankalaa muistaa esimerkiksi sitä, millaiseksi hän ajatteli Lähettiläs EzRan saapumista seuraavan katastrofin, kun hän luki siitä ensimmäisen ennakoinnin:

That was the moment everything changed. EzRa looked at each other, smiled. Their first official pronouncement. If it hadn't been an absurd faux pas I think we would all have clapped. I'm sure many people hadn't really thought them capable.

We were busy listening to them speak, and gauging their abilities. We didn't notice anything change. I don't think any of us at that moment noticed the reactions of the Hosts. (Embassytown, 104.)

Embassytownissa avointen mahdollisuuksien aiheuttamaa jännitystä tai jännitettä käytetään toistuvasti hyväksi. Siirrynkin seuraavaksi tarkastelemaan yksityiskohtaisemmin fiktiivisen maailman ja tarinamaailman välistä vuorovaikutusta, johon ei aiemmassa tutkimuksessa ole juuri perehdytty. Fantasiakerronnan tutkimus on korostanut lukijan mielikuvituksellista uppoutumista maailmaan, kun taas maailmaan luonnollistamisen tai selittämisen välineenä keskittyvässä narratologisessa tutkimuksessa fiktiivisen maailman viehätys tai immersiivisyys on jäänyt pimentoon. Pyrin nyt osaltani paikkaamaan tätä puutetta.

\section{Maailmojen rakentaminen kehämäisenä prosessina}

Luonnottoman narratologian pääpiirteet tiivistävässä artikkelissa Jan Alber, Stefan Iversen, Henrik Skov Nielsen ja Brian Richardson (2010, 114) esittävät, että kertomukset ovat täynnä niin sanottuja luonnottomia elementtejä, ja että monet niistä "uhmaavat, pilkkaavat, leikittelevät tai kokeilevat joitakin (tai kaikkia) kertomuksen perusoletuksista”. Luonnottoman narratologian projektin tärkein panos kirjallisuudentutkimukselle on ollut se, että se kiinnittää huomiomme siihen tosiasiaan, että kirjallisuutta ei ymmärretä automaattisesti. Lukijoiden on tehtävä huomattava määrä työtä tekstejä tulkitessaan. Toisaalta tämänkaltainen outous ei ole pelkästään kokeellisen fiktion piirre, kuten luonnoton narratologia näyttäisi olettavan. Päinvastoin, se sijoittuu kaunokirjallisiin konventioihin itseensä (vrt. Tammi 2006, 30), ja sitä voidaan tarkastella esimerkiksi fiktiivisen maailman ja lukijan konstruoiman tarinamaailman välisen vuorovaikutuksen tai jännitteen kautta.

Embassytown tekee tarinamaailman rakentamisesta melko haasteellista. Koska romaanin minäkertojana on Avice, fiktiivisen maailman syntyperäinen hahmo, monia lukijalle täysin outoja asioita ei juurikaan avata tai kuvailla kerronnassa. Kun lukija 
esimerkiksi ensimmäisen kerran kohtaa Lähettiläät, heidän olemustaan ei selitetä mitenkään:

"What about the rest of the Ambassadors?" I said.

We looked around the room. Many of their colleagues had arrived now. I saw

EsMé in iridescent dresses; ArnOld fingering the tight collars wedged uncomfortably below their links; JasMin and HelEn debating complexly, each Ambassador interrupting the other, each half of each Ambassador finishing their doppel's words. So many Ambassadors in one place made for a dreamish feel. Socketed into their necks and variously ornamental, according to taste, diodes in their circuited links staccattoed through colours in simultaneous pairs.

"Honestly?" said EdGar. "They're all worried." "To various degrees." "Some of them think we're..." "...exaggerating. RanDolph thinks it'll all be good for us." (Embassytown, 52-53.)

Lukijalle kyllä selviää, että Lähettiläät ovat kaksoisolentoina työskenteleviä pareja, että he ovat poikkeuksellisen läheisiä keskenään ja että heidät on liitetty yhteen jollakin oudolla teknologialla. Mutta kuinka tämä on tehty, ja etenkin miksi se on tehty, paljastuu vasta paljon myöhemmin, kun Ariekein Kielen luonne selviää. Siihen asti lukijan on vain siedettävä fiktiivisen maailman outoutta ja tehtävä parhaansa dekoodatakseen sellaisia sanoja kuin "Turingware" (laitteisto, joka simuloi näennäisen tietoisuuden tietokoneille) tai "miab" ("pullo", joka kuljettaa viestejä immerin halki). Vaikka tämänkaltainen outous on omiaan vaikeuttamaan lukijan tekemää tarinamaailman konstruointia, se on silti konkreettisella tai materiaalisella tavalla lähtöisin kerronnan aktuaalisena esittämän maailman alueelta. Tämä voidaan nähdä nimenomaan fantasiakerronnalle tyypillisen outouden lähteenä, joka hyödyntää lineaariselle lukuprosessille ominaista dynamiikkaa.

Mitä lukijat sitten tekevät tällaista outoutta kohdatessaan? Jan Alber on väittänyt, että vain "zeniläisen lukutavan" omaksuva lukija voisi "tyynesti hyväksyä epäluonnollisten tapahtumien outouden" (Alber 2010, 50). Jostain syystä hän näyttää olettavan, että outous aiheuttaisi lukijassa epämukavuuden, pelon tai huolestumisen tunteita. Tämä saattaa pitää paikkansa Alberin tarkastelemissa teksteissä, sillä niissä tuntemamme todellisuus itsessään on uhattuna. Oletus ei kuitenkaan päde Miévillen romaanin kohdalla, sillä siinä outous on pikemminkin kiinnostuksen kohde. Le Guin paikantaa tämän esimerkiksi niin sanottujen laatikkosanojen dekoodaamiseen: ”[M]ielikuvitukselliset hypyt ja lukijoiden älyn arvostaminen voivat olla merkittäviä mielihyvän lähteitä lukemisessa." (Le Guin 2011.) Lukijan on pyrittävä avaamaan laatikkosanat, jotta hän voisi ymmärtää niiden merkityksen ja sen, mihin niillä viitataan. Hyvä esimerkki tällaisesta ilmauksesta on "trid jewellery" (Embassytown, 49), joka pienen miettimistauon jälkeen avautuu tarkoittamaan kolmiulotteisia koruja, tai edellä mainittu "miab", joka muodostuu sanojen "message in a bottle" alkukirjaimista. Laatikkosanat osoittavat sen, että kuvitteellisia maailmoja rakentava fiktio voi olla onnistunutta juuri silloin, kun se ei luovuta maailmaansa liian helpolla vaan haastaa lukijansa maailmanrakentamiskyvyt. 
Tämä piirre myös korostaa kaunokirjallista outoutta, sillä se on yksi niistä tavoista, jolla lukijan tarinamaailman konstruointia hidastetaan.

Miévillen romaanissa hidastaminen liittyy fantasiakerronnassa tyypilliseen tutun ja oudon väliseen rajankäyntiin. Laatikkosanojen dekoodaaminen on osa laajempaa tulkintaprosessia, jonka tuloksena lukija voi nähdä omasta todellisuudestaan täysin erillisen maailman kuitenkin käsittelevän sitä. Tältä kannalta spekulatiivisen fiktion maailmojen konkreettisuus liittyy myös tiettyjen ideoiden kommunikoimiseen tai materialisoimiseen. Embassytownin voi esimerkiksi nähdä käsittelevän ihmiskielen luonnetta asettamalla sen rinnakkain Ariekein Kielen kaltaisen fantastisen innovaation kanssa. Tällaisesta kielestä ei puolestaan tulisi mahdollista tai ainakaan yhtä saavutettavaa, jos sitä ei sijoitettaisi maailmaan, joka luo sille uskottavan kontekstin. Tämänkaltainen maailmojen konkreettisuus näkyy jo Tolkienin käsityksessä kuvitteellisen maailman koherenssista. Hän käyttää esimerkkinään "vihreää aurinkoa”, jonka kuvitteleminen ja kuvaaminen eivät niinkään ole vaikeita tehtäviä, mutta sellaisen maailman luominen, jonka sisällä vihreä aurinko olisi uskottava, vaatii erityistä työtä ja pohdintaa (vrt. Tolkien 2002, 68). Uskottavuuden ohella Tolkienin ajatus kertoo myös olennaisen piirteen kuvitteellisten maailmojen estetiikasta: maailma, joka kokonaisuutena kommunikoi jotakin merkityksellistä lukijalleen, on kiinnostavampi kuin maailma, joka on olemassa ollakseen ainoastaan vaikkapa pseudokeskiaikaan tai avaruuteen sijoittuvien taistelujen kehys.

Kaiken kaikkiaan kekseliäät laatikkosanat ja muut vastaavat keinot nostavat esiin sen, että maailmojen rakentaminen on pohjimmiltaan kehämäinen prosessi, jota pohdin seuraavaksi. Sen yhteydessä lukijan tapaa kuvitella maailmoja tulisi painottaa enemmän suhteessa ilmaisuun ja keinoihin, jotka luovat maailman taiteellisena ilmiönä. Kognitiivinen narratologia on tarjonnut uusia keinoja lukijan aktiivisen toiminnan painottamiseen fiktion maailmojen tarkastelun yhteydessä. Alan Palmer $(2004,34)$ esimerkiksi on erottanut kolme lukemisen - eli fiktiivisen maailman tavoittelun - sisältämää tasoa. Ensimmäinen näistä on lähdetaso (source domain) eli todellinen maailma, jossa lukija prosessoi tekstin, ja toinen kohdetaso (target domain) eli tarinamaailma, joka muodostaa lukijan prosessoinnin tuotteen. Kolmannen tason muodostaa teksti, eli Palmerin mukaan tekstuaalisten keinojen järjestelmä. Se herättää erilaista lukijakohtaista todellisen maailman tuntemukseen liittyvää tietoa, joka heijastaa lukijan lähdetasolta kohdetasolle. Huomionarvoista Palmerin mallissa on se, että maailmojen rakentaminen näyttäisi sen mukaan toimivan ainoastaan yhteen suuntaan, eli lähdetasolta kohdetasolle tekstuaalisten keinojen välityksellä. Fiktiivinen maailma toki on riippuvainen todellisesta maailmasta siellä tehtyjen sekä siihen perustuvien valintojen ja tulkintojen puolesta, mutta toisaalta se vastavuoroisesti ohjaa lukijaa tekemään tietynlaisia oletuksia todellisessa maailmassa tehtävästä toiminnasta. Se ei ole vain passiivinen objekti tai kertomuksen luomisen väline, johon ei ole pääsyä, vaikka kertovaan tekstiin keskittyvä tutkimus saakin sen sellaiselta usein näyttämään. 
Lukijan rakentama tarinamaailma on tapa tehdä fiktiivisestä maailmasta mahdollinen tai saavutettava. Laatikkosanojen kaltaisten outouksien dekoodaamisen ohella keskeinen strategia tässä on edellä mainitsemieni sisäkkäismaailmojen konstruoiminen. Se mahdollistaa paitsi tiettyjen asioiden, tapahtumien ja olentojen aktuaalisuuden määrittämisen myös position ottamisen maailman sisältä. Voidakseen ymmärtää omasta kokemusmaailmastaan erillistä todellisuutta lukijan on Hermanin $(2002,15)$ mukaan mielikuvituksen keinoin siirryttävä niihin aika-avaruudellisiin koordinaatteihin, jotka järjestävät fiktiivisen maailman havaitsemista ja tulkintaa. Tämän käsityksen mukaan jo Embassytownin aloittava lause "The children of the embassy all saw the boat land" vaatii deiktistä siirtymää (deictic shift) maailmaan, jossa näkeminen ja aluksen laskeutuminen tapahtuvat. Marco Caracciolo $(2011,118)$ puolestaan esittää tuoreessa artikkelissaan, että kertovat tekstit kutsuvat lukijaansa siirtymään fiktiivisiin maailmoihin osana niiden yhteistä konstruointia. Hän tarkastelee ilmiötä käsitteellä "lukijan virtuaalisesta ruumiista", joka "viedään" kuvitteelliseen maailmaan. Vaikka Caracciolon ajatus on kiinnostava, se ei ota kaunokirjallisuuden välittyneisyyttä huomioon riittävällä tavalla. Hänen ajatuksensa seuraaminen sellaisenaan tarkoittaisi liian pitkän hypyn tekemistä: hyppäisimme konkreettisen taiteellisen työn yli ja näin ollen ohittaisimme fiktiivisen maailman rakentamisessa käytetyt keinot ja konventiot.

Palmer on tarttunut Ryanin käsitykseen tekstuaalisen aktuaalisen maailman ympärille sijoittuvista sisäkkäismaailmoista, mutta pyrkinyt kytkemään sen vahvemmin lukijan aktuaaliseen kognitioon ja näin myös lukijan tekstin ymmärtämisen prosesseihin. Hän esittää Ryanin käsitteisiin pohjaten, että lukija pystyy lukemaan fiktiivisen henkilön tajuntaa laajempaan kontekstiin upotettuna kertomuksena (embedded narrative) sovittamalla siihen jatkuvan tietoisuuden kehyksen (continuing-consciousness frame). Tätä kautta lukija voi konstruoida henkilön koko mielen toiminnassa: mukana ovat niin aistinvarainen ja kognitiivinen perspektiivi kokonaisuudessaan, ideologinen maailmankuva, muistot menneestä kuin uskomusten, halujen, aikomusten ja motiivien kokoelma sekä tulevaisuudensuunnitelmat. (Palmer 2004, 175, 183-184.) ${ }^{8}$ Näin hahmottuu kokonaiskuva henkilöhahmon subjektiivisesti konstruoimasta tarinamaailmasta, joka on jatkuvassa vuorovaikutuksessa muiden henkilöiden maailmojen ja ympäröivän fiktiivisen maailman kanssa. Sisäkkäismaailman voikin nähdä leikkaavan yksilöllisen siivun kerronnassa aktuaalisena esitetyn fiktiivisen maailman kudoksesta. Se kuvaa henkilöhahmon mentaalista mallia fiktiivisestä maailmasta: kuinka hän rakentaa siitä merkityksiä, ymmärtää sitä ja navigoi siellä.

Tällaisten jatkuvien tietoisuuksien rakentaminen on yksi lukijan keinoista "tekstuaalisen kaaoksen" taltuttamiseen, sillä niiden avulla voidaan koettaa hahmottaa sitä, onko jokin tietty kerronnassa kuvattu tapahtuma todellinen vai onko se uskomus, toive, pelko, uni, harha, kuva tai vaikkapa tietokoneen simuloima kokemus. Toisaalta 
on tärkeää huomioida se, että kaunokirjallisuudessa tällaiset perusmekanismit voidaan myös tehdä näkyviksi venyttämällä niitä, leikittelemällä niillä tai suorastaan estämällä niiden toiminta. Erillisiksi kokonaisuuksikseen hahmotettavia maailmoja rakentavassa fiktiossa esimerkiksi epäluotettavan kertojan käyttäminen ei kuitenkaan ole yleinen konventio, sillä se haittaisi huomattavasti lukijan immersiota maailmaan. Samalla myös koko tekstin luonne fantasia- tai tieteisfiktiona muuttuisi, kun lukija ei enää voisi olla varma siitä, ovatko esimerkiksi kerronnassa kuvatut tapahtumat seurausta fiktiivisen maailman fantastisuudesta vai kenties kertojan harhoja. ${ }^{10}$ Seuraava katkelma, jossa kuvataan yhtä Ariekei-olentoa, olisikin lukijan tarinamaailman rakentamisen kannalta hyvin erilainen, jos se olisi tulkittavissa Avicen uneksi, harhaksi tai unelmaksi eikä niinkään aktuaalisen maailman kuvaukseksi:

Waving on a stalk-throat by its neck, its Cut-mouth terribly like human lips, the Host muttered: and at the level of our chests, where its body swelled, its Turn-mouth opened and coughed, emitting little rounded vowel sounds, tao dao thao. [--]

$\frac{\text { kora }}{\text { shahundi }}$ stepped forward on four legs a little like a spider's, long, too-jointed, dark-haired, and extended its wings: from its back its auditory fanwing, in many colours; from its front, from below its larger mouth, its limb of interaction and manipulation, its giftwing. (Embassytown, 91-92.)

Kaiken kaikkiaan minäkertoja Avicen "jatkuvan tietoisuuden" rakentaminen, hänen näkemisensä todellisen ihmisen kaltaisena, on yksi Embassytownia kokonaisuutena järjestävistä keinoista. Niin sanottuun tosielämän kokemukseen tämä prosessi viittaa siinä mielessä, että se luo illuusion lineaarisesta kulusta, jollaisen kokijaksi todellinen ihminen aikaan ja tilaan sijoittuneena ruumiina mielletään. Näin ollen se siis luo kuvaa siitä, että esimerkiksi fiktiivisen maailman tapahtumat tapahtuvat jollekulle ja vaikuttavat johonkuhun samaan tapaan kuin todellisessakin maailmassa. Toisaalta fiktiivisen mielen tapa aavistaa ennalta välittämisensä akti - eli aktuaalinen lukukokemus - purkaa käsitystä fiktiivisestä mielestä tai fiktiivisestä maailmasta pohjimmiltaan todellisen kaltaisina. Tällä tarkoitan sitä, että ne ovat tietoisesti lukemista varten sommiteltuja.

Avicen mieli on hyvä esimerkki siitä, kuinka fiktiiviset henkilöhahmot sommittelevat kokemustaan kielellisesti, kerronnallisesti ja myös taiteellisen motivaation kautta (vrt. Mäkelä 2011, 45). Erityisen konkreettisesti tämä näkyy Embassytownin rakenteessa.Romaani alkaa luvulla nimeltä "Proem", jossa valotetaan Avicen taustaa. Siinä kerrotaan, kuinka hän kasvoi Ariekalla, kuinka hänestä tuli immerseri ja kuinka hän tapasi kieltentutkija Scilen, tulevan aviomiehensä: "I know exactly how I'd have looked: leaning back in my high chair, turned so resting my back against the bar top, my head back so I could look down at him.” (Embassytown, 39.) Sen jälkeen kerronta siirtyy vuorottelemaan kahdenlaisten lukujen välillä, jotka on nimetty otsikoin "Latterday" ja "Formerly". Otsikon "Latterday" alla olevat luvut kertovat, kuinka 
geneettisesti muuntelematon lähettiläs EzRa saapuu ja muuttaa kaiken. Lähettilään puhe vaikuttaa Ariekeihin huumeen tavoin, pikku hiljaa heistä tulee säälittäviä narkomaaneja ja koko planeetta ajautuu sodan partaalle. Otsikolla "Formerly" varustetut luvut puolestaan kuvaavat aikaa ennen kriisiä. Lukija saavuttaa kerronnan nykyhetken vasta aivan romaanin loppupuolella ja joissakin pienissä katkelmissa lukujen lomassa:

Later, the scale of the crisis that unfolded made this, retrospectively, a guilty memory, but when I first realised that things were not going quite to plan, the first time I met EzRa at the Arrival Ball, when I sensed that they were spreading some unexpected chaos in Embassytown, it had made me happy. (Embassytown, 187.)

Embassytown kyseenalaistaa Palmerin $(2004,11)$ väitteen siitä, että lukijan kohtaaminen fiktiivisten henkilöhahmojen kanssa muistuttaa paljolti tutustumista todellisiin ihmisiin. Sen rakenne rikkoo ajatuksen Avicen mielestä todellisen kaltaisena ja pikemminkin vahvistaa mielikuvaa hänen "äänestään” tietoisesti konstruoituna osana konkreettista taiteellista ilmiötä. Lopulta tämän käsittelyni tarkoituksena ei ole julistaa upotetun kertomuksen tai jatkuvan tietoisuuden kehyksen käsitteitä hyödyttömiksi vaan ainoastaan osoittaa niiden keinotekoisuus - tai luonnottomuus, jos niistä sellaista nimitystä halutaan käyttää. Tapa, jolla lukija ymmärtää henkilöhahmoja ja siten eläytyy fiktiiviseen maailmaan, jonka henkilöhahmot puolestaan kokevat, ei olekaan verrannollinen tapaan, jolla lukija hahmottaa todellista maailmaa. Sen sijaan se vertautuu tapaan, jolla lukija itse konstruoi kaunokirjallista tekstiä. Maria Mäkelä $(2011,272)$ on osuvasti todennut, että kirjallinen esitystapa tekee mahdolliseksi "kognitiivisen tempun", jossa sekä kokeminen, kertominen että koko fiktiivisen maailman ja henkilöiden konstruointi tapahtuvat kaikki samalla tasolla. Ne rakentuvat silmukoissa tai kehissä, joissa fiktiivinen maailma ja siitä tehdyt havainnot, siellä nähdyt unet, sen suhteen toivotut haaveet ja siellä tavoitellut unelmat nivoutuvat yhteen. Embassytownin kaltaisten teosten yhteydessä on lisäksi hyvä huomioida se, että fiktiivinen maailma yhtä lailla on konstruktio, joka aavistaa rakentamisensa ennalta. Siksi Embassytown on täynnä tunnistettavia ja sommiteltuja elementtejä, joihin lukija voi tulkinnallaan tarttua paitsi todellisen maailman tuntemuksensa pohjalta myös suhteessa muihin fiktiivisiin maailmoihin.

\section{Lopuksi: Mahdottoman ja mahdollisen välissä}

Tässä artikkelissa käsitelty Miévillen Embassytown nostaa esiin sen, että sekä kaunokirjallisuuden outous että viehätys voivat pohjautua mahdottoman ja mahdollisen vuorovaikutukseen tai jännitteeseen. Havainnollistin tätä jännitettä kahden mahdollisten maailmojen poetiikasta ja narratologiasta johdetun teoreettisen työkalun, fiktiivisen maailman ja tarinamaailman, avulla. Fiktiivinen maailma on keino tavoittaa jotakin kaukaista ja "mahdotonta" rakentamalla siitä ymmärrettävä kokonaisuus tai tekemällä 
siitä materiaalinen. Tarinamaailma puolestaan havainnollistaa lukijan tapaa hahmottaa fiktiivistä konstruktiota niin, että sekä kirjallisuudelle tyypilliset keinot että aktuaalinen lukuprosessi pysyvät tiiviisti mukana analyysissa. Tarinamaailma on siis tulkinnan väline, keino, jolla tekstin esittämiä erilaisia mahdollisuuksia voidaan punnita.Tältä kannalta maailmoihin perustuva malli tavoittaakin kaunokirjallisten tekstien dynamiikan - sellaisena kuin se lukijan ja tekstin vuorovaikutusprosessissa muodostuu - paremmin kuin vaikkapa tarinaan ja kerrontaan perustuva kaksijakoinen malli.

Miksi mahdottoman ja mahdollisen välisen vuorovaikutuksen käsitteleminen sitten on tärkeää? Ensinnäkin maailmojen kautta voidaan pohtia sitä, mihin Embassytownin kaltaisen spekulatiivisen fiktion outous ja viehätys sijoittuvat suhteessa muunlaiseen fiktioon. Tarkasteluni antoikin yhdenlaisen vastauksen siihen, mihin niin sanottuja sekundaarisia maailmoja tarvitaan. Toisaalta fiktiivisten maailmojen tutkijoiden tulisi tunnistaa tietyille medioille tyypillisten konventioiden ja piirteiden merkitys. Kertovaan tekstiin keskittyvä analyysi on usein synnyttänyt vaikutelman siitä, ettei fiktiiviseen maailmaan ole pääsyä, sillä se on vain kerronnallisin (ja usein kielellisin) keinoin tuotettu objekti. Maailmoihin perustuva lähestymistapa paitsi nostaa esiin taiteellisen konstruktion ja sen pohjalta syntyvien kuvitelmien välisen vuorovaikutuksen myös auttaa välttämään kerrontaan keskittyvien teorioiden pohjalla vaikuttavan olettamuksen verbaalisesta kommunikaatiosta. Se, että ihmismieli on pohjimmiltaan maailmoja rakentava, ei tarkoita sitä, että se olisi myös kirjallinen. Ei ole mitään syytä väittää, että kirjallisuus olisi meille kaikkein ominaisin tapa välittää ymmärrystämme maailmankaltaisista konstruktioista toisille.

Lopulta maailmojen sijoittaminen mahdottoman ja mahdollisen väliselle rajapinnalle osoittaa sen, että vaikka kykenemme mielikuvituksen keinoin hyppäämään kohti jotakin tuntematonta tai outoa, hyppymme ei koskaan tavoita toista mieltä tai toisen kokemusta. Yhtä lailla ensin tullut maailma liukuu pois ulottuviltamme: sen hahmottaminen kaiken alkulähteeksi on ainoastaan yksi tulkintastrategioistamme. En käytä sanaa "ainoastaan" siksi, että pitäisin tällaisia strategioita vähäarvoisina, vaan korostaakseni fiktiivisten maailmojen keinotekoisuutta. Emme siis koskaan tavoita maailmaa siinä muodossa ja ulkoasussa, joka tuli ensin, mutta halumme tavoittaa se avaa väylän mahdollistavan maailman rakentamiselle. Kaiken kaikkiaan tämä lähestymistapa fiktiiviseen maailmaan viittaa siihen, että emme lue ainoastaan saadaksemme selville, mitä seuraavaksi tapahtui, tai siksi, että haluaisimme nauttia kyvystämme lukea henkilöhahmojen ajatuksia. Yhtä lailla voimme lukea myös löytääksemme maailman, jota ei vielä ole. 


\section{Viitteet}

${ }^{1}$ Kontrafaktuaali tarkoittaa sellaista ehdollista väitettä, jonka alkuosa ilmaisee jotakin tosiasioiden vastaista. Esimerkiksi "Jos olisin tiennyt..." tai "Jos hän olisi nähnyt...". ${ }^{2}$ Samuli Hägg $(2008,5)$ lainaa tämän termin Raine Koskimaalta $(1999,133)$. Hägg määrittelee mahdollisten maailmojen poetiikan kirjallisuudentutkimukseksi, joka hyödyntää mahdollisten maailmojen semantiikan käsitteistöä kertomusteoriassa ja kaunokirjallisten kertomusten analyysissa ja tulkinnassa. Käytän tätä tarkempaa termiä useasti käytetyn lavean "mahdollisten maailmojen teorian" sijasta tässä artikkelissa.

${ }^{3}$ Teoksen spekulatiivisen kielen vuoksi sitaatit on tässä tapauksessa poikkeuksellisesti esitetty alkukielellä. Embassytownia ei ole toistaiseksi käännetty suomeksi.

${ }^{4}$ Kummallinen on sopiva adjektiivi Miévillen teosten kuvaamiseen siitäkin syystä, että hänen Perdido Street Station -romaaniaan (2000) pidetään merkittävimpänä niin sanotun uuskumman (New Weird) fantasiafiktion edustajana. Jotkut kirjailijat ja kriitikot ovat nähneet tämän genren (tai kirjallisen liikkeen) peräti osoituksena taiteellisesta vallankumouksesta (vrt. VanderMeer\&VanderMeer 2008), mutta uuskumman yleisimmät tunnuspiirteet liittyvät sen kaikenlaisia luokitteluja pakenevaan luonteeseen ja siihen, että se ponnistaa genrefantasiasta poikkeavasta fantasiakerronnan traditiosta.

${ }^{5}$ Sijoitan tässä Miévillen romaanin historiallisesti määriteltävän fantasiakerronnan alle, vaikka käytänkin sen rinnalla laajaa spekulatiivisen fiktion käsitettä. Tämän tarkemmin en lähde tässä romaania geneeriselle kentälle sijoittamaan: Johanna Sinisalo esimerkiksi on havainnollistanut fantastisen kerronnan eri alueiden määrittelyn monimutkaisuutta "mandalallaan" (ks. Sinisalo 2004, 17).

${ }^{6}$ Tämä termi on lähtöisin J.R.R. Tolkienin primääristä ja sekundaarista maailmaa koskevasta teoriasta, jonka hän alun perin esitti "Saduista"-luennollaan (julkaistu esseenä 1947). Sen mukaan primäärinen maailma on arkikokemuksemme tuttu maailma, jossa ovat voimassa luonnon lait, kun taas sekundaarinen maailma syntyy kirjailijan ja lukijan yhdessä olettamana ja kuvittelemana. Luodessaan sekundaarisen maailman, johon lukijan mieli voi astua sisään, tarinantekijä osoittautuu menestyksekkääksi "alemmaksi luojaksi". Sekundaarisen maailman sisällä asiat, joista tekijä kertoo, ovat "totta": ne ovat sopusoinnussa tuon maailman lakien kanssa. (Tolkien 2002, 55.)

${ }^{7}$ Järjestys on päinvastainen verrattuna Aristoteleen tunnettuun väitteeseen siitä, että juoni (mythos) ja toiminta (praxis) loogisesti edeltävät fiktion muita osa-alueita.

${ }^{8}$ Tämän artikkelin tila ei valitettavasti riitä sen tarkasteluun, millä kaikilla tavoilla lukija voi erotella henkilöhahmon mieltä muusta kertovasta kontekstista.

${ }^{9}$ Käytän tätä metaforaa tavoittaakseni perustavanlaatuisen yhteyden, jonka mukaan tila ja aika ovat poimuttuneet yhteen aika-avaruudeksi, josta kukin havainnoija "leikkaa" oman havaintonsa (vrt. Albert Einsteinin suhteellisuusteoria). Kirjallisuudentutkimuksen piirissä Einsteinin teoria on toiminut pohjana Mihail Bahtinin kronotoopin (chronotope; sananmukaisesti aika-avaruus) käsitteelle. Bahtinin $(1987,84)$ mukaan kronotooppi kuvaa temporaalisten ja spatiaalisten suhteiden erottamattomuutta, joka ilmenee taiteellisesti kirjallisuudessa.

${ }^{10}$ Nykyaikaisessa spekulatiivisessa fiktiossa toki esiintyy tällaistakin ambivalenttia leikkiä: esimerkiksi Kathe Kojan novellissa "The Neglected Garden" (1991) voimaan jää (tai voi jäädä) kaksi toisistaan eroavaa tulkintaa novellin tapahtumien fantastisuudesta. Kerronnassa kuvattu maailma on silti hyvin immersiivinen ja kiinnostava jo itsensä takia. 


\section{Lähteet}

ALBER, JAN 20IO: Mahdottomat tarinamaailmat - ja mitä niillä voi tehdä. Teoksessa Luonnolliset ja luonnottomat kertomukset. Jälkiklassisen narratologian suuntia. Toim. Mari Hatavara, Markku Lehtimäki \& Pekka Tammi. Suom. Laura Karttunen. Gaudeamus: Helsinki.

ALBER, JAN; IVERSEN, STEFAN; NIELSEN, HENRIK SKOV \& RICHARDSON, BRIAN 2OIO: Unnatural Narratives, Unnatural Narratology: Beyond Mimetic Models. NARRATIVE 18:1, 113-136.

BaHtin, MiHail 1987: Forms of Time and of the Chronotope in the Novel [19371938]. Teoksessa The Dialogic Imagination: Four Essays. Ed. by M. Holquist, Transl. M. Holquist \& C. Emerson. Austin: University of Texas Press, 84-258.

BROOKe-ROSE, CHristine I986: A Rhetoric of the Unreal. Studies in Narrative \& Structure, Especially the Fantastic. Cambridge: Cambridge University Press.

Caracciolo, marco 20i i: The Reader's Virtual Body. Narrative Space and Its Reconstruction. Storyworlds: A Journal of Narrative Studies. Vol 3, 117-138.

Doležel, Lubomír I998: Heterocosmica. Fiction and Possible Worlds. Baltimore: The Johns Hopkins UP.

FLUDERNIK, MONIKA I993: The Fictions of Language and the Languages of Fiction: The Linguistic Representation of Speech and Consciousness. Lontoo: Routledge.

HeRman, DAVID 2002: Story Logic: Problems and Possibilities of Narrative. Lincoln: University of Nebraska.

HÄGG, SAMULI 2005: Narratologies of Gravity's Rainbow. University of Joensuu Publications in the Humanities 37. Joensuu: University of Joensuu.

HÄGG, SAMULI 2008: Lisää käyttöä mahdollisille maailmoille. Kirjallisuudentutkimuksen aikakauslehti Avain 3/2008, 5-21.

IHONEN, MARIA 2002: Fantastinen fiktio mahdollisten maailmojen teorian valossa. Teoksessa Merkkejä ja symboleja. Esseitä kirjallisuudesta ja sen tutkimuksesta. Toim. Markku Lehtimäki. Tampere: Tampere UP, 184-203.

koskimaA, Raine i999: Possible Worlds in Literary Theory. Poetics Today 20:1, 133138.

LE Guin, URSUla K. 20I I: Embassytown by China Miéville - review. The Guardian, 7.5.2011.

MIÉville, CHINA 2009: There and Back Again: Five Reasons Tolkien Rocks. <http:// www.omnivoracious.com/2009/06/there-and-back-again-five-reasons-tolkien-rocks. html.>

MIÉVILLE, CHINA 20I I: Embassytown. London: MacMillan.

MÄKELÄ, MARIA 20 I I: Uskoton mieli ja tekstuaaliset petokset. Kirjallisen tajunnankuvauksen konventiot narratologisena haasteena. Tampere: Tampere University Press. 
PALMER, ALAN 2004: Fictional Minds. Lincoln \& Lontoo: University of Nebraska Press. PAVEL, THOMAS I 986: Fictional Worlds. Cambridge: Harvard UP.

ryan, marie-laure i99i: Possible Worlds, Artifical Intelligence, and Narrative Theory. Indiana: University of Bloomington \& Indianapolis Press.

Ryan, Marie-Laure I992: Possible Worlds in Recent Literary Theory. Style 26, 528 554.

RYAN, MARIE-LAURE 200I: Narrative as Virtual Reality: Immersion and Interactivity in Literature and Electronic Media. Baltimore: Johns Hopkins UP.

SINISALO, JOHANNA 2004: Fantasia lajityyppinä ja kirjailijan työvälineenä. Teoksessa Fantasian monet maailmat. Toim. Kristian Blomberg, Irma Hirsjärvi\& Urpo Kovala. Helsinki: BTJ Kirjastopalvelu, 11-31.

TAMMI, PEKKA 2006: Against Narrative ("A Boring Story"). Partial Answers: Journal of Literature and the History of Ideas 4:2, 19-40.

tOlkien, J. R. R. 2002/I 964: Puu ja lehti. Suom. Vesa Sisättö. Helsinki: WSOY.

traill, Nancy H. 1996: Possible Worlds of the Fantastic. The Rise of the Paranormal in Literature. Toronto: University of Toronto Press.

VANDERmeer, JefF \& VANDERmeer, ANn (ed.by) 2008: The New Weird. San Francisco: Tachyon Publications. 